\title{
Synthetic gene firms evolve toward sustainable business?
}

A raft of companies offering stretches of synthetic DNA built to customer specifications at low cost have been attracting biotechs' attention with promises of ever-longer strands. But whether such companies have a viable business model for the long term is yet to be shown. Providing on-demand synthetic biology services alone may not be enough. That activity may need to be complemented by creative proprietary applications exploiting the synthetic genes ordered.

Considering the growing need for DNA among academic and industry scientists, the sector should face a promising future, says Rich Fisler, the president of consultancy Beachhead Consulting in Park City, Utah. According to Fisler's estimates, the global market for synthetic reagents currently tops $\$ 600$ million, of which more than half come from sales of synthetic genes and oligonucleotides, with smaller contributions from peptides, RNA interference molecules and antibodies. Total sales could pass $\$ 3$ billion by 2015, he predicts. "We're making picks and hammers," explains Ralf Wagner, the CEO of GeneArt, a synthetics reagent firm in Regensberg, Germany. "So, we're not involved in high-risk product development like the drug company startups. We're just selling tools to support different areas in the life sciences and accordingly we have a very large customer base."

But to reach that potential, companies will have to meet evolving demands for more complex structures, such as functional stretches of DNA containing more than one gene, adds venture capitalist David Stone, from Flagship Ventures, in Cambridge, Massachusetts. "Just making DNA and selling it by the base pair isn't a very inspiring business model," he says. "The business gets more interesting when you can deliver enough size and sophistication to tackle problems that scientists wouldn't previously consider. You need to understand the killer applications well enough to ensure your platform enables your clients to pursue them."

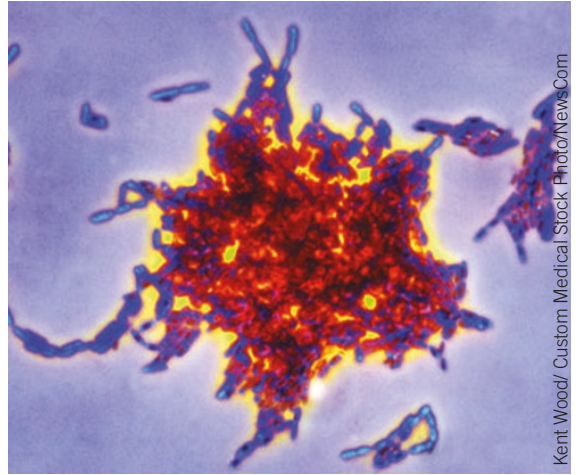

Some speculate that the ability to produce ondemand synthetic genes could be coopted for nefarious creation of new agents of potential virulence that could rival (or even surpass) that of natural pathogens, such as anthrax (pictured here).

Advanced applications fitting that criteria, Stone says, include optimizing key steps in metabolic pathways, or producing high-value synthetic intermediates for products like new drugs.

The synthetic reagents industry grew from advances in gene assembly, and also from error reduction methods that made it possible to optimize genes for stability, mainly by removing repetitive sequences. "Synthetic processes now allow you to reliably generate most of the same molecules you get from conventional biology in addition to designer proteins," says John Mulligan, the CEO and founder of Blue Heron Biotechnology, a synthetics reagents firm located in Bothel, Washington. "But the core business is still assembling DNA oligonucleotides and cloning them to make bigger fragments."

With the growth of gene synthesis, costs have dropped sharply, from an average of $\$ 12$ per base pair in the 1990 s, to roughly $\$ 1.50$ today. Meanwhile, synthetic DNA fragments have gotten progressively larger. In July, 2006, Codon Devices, a small startup in Cambridge, Massachusetts, manufactured and sold a stretch of synthetic DNA $>35,000$ base pairs long,

Table 1 Selected synthetic reagents companies

\begin{tabular}{ll} 
Company & Applications \\
\hline $\begin{array}{l}\text { Blue Heron Biotechnology } \\
\text { (Laguna Hills, California) }\end{array}$ & Gene synthesis \\
\hline Codon Devices & Synthesis of genes with 'silent' mutations \\
\hline DNA 2.0 & $\begin{array}{l}\text { Gene synthesis, protein development, enzymes, cell factories, } \\
\text { synthetic biology }\end{array}$ \\
\hline GeneArt & Custom gene synthesis, proteins \\
$\begin{array}{l}\text { Sloning Biotechnology } \\
\text { (Puchheim, Germany) }\end{array}$ & Gene synthesis, combinatorial chemistry, industrial enzymes \\
\hline
\end{tabular}

Source: company websites. claiming it was the largest commercially produced strand to date.

But although they push the limits of production, these mega-fragments don't reflect typical market demands, according to Mulligan. "The vast bulk of what people need now are DNA stretches in the 500 to 10,000 base pair range," he says. Mulligan expects production sizes to increase as scientists pursue more complex projects, such as assembling microbial genomes for synthetic biology. Toward that end, he expects the industry to shift from a general base in laboratory-oriented processes towards automated, industrialized platforms. This high-throughput trend, he says, will heighten production capacity while pushing costs down even further.

However, Stone cautions that falling costs for synthetic reagents could be a double-edged sword-to prosper while prices fall, companies will have to stimulate correspondingly larger sales. "If you drop your costs by tenfold you better sell at least ten times as much product," he warns. A way for companies to sustain their viability, he suggests, could be with innovative applications that go beyond mere gene synthesis. "If two companies make DNA for the same cost, but one has innovative ideas about what to do with it, then that company has a competitive advantage," he says.

Deeper integration with downstream product development goals could also raise patent issues, however. As it stands now, companies in this area typically have no interest in their customer's intellectual property. "We make the genes our customers want and the intellectual property from those genes belongs to them," says Jeremy Minshull, the President of DNA 2.0, in Menlo Park, California. But not all companies favor this approach. GeneArt, for instance, does negotiate for intellectual property if their gene optimization processes substantially enhance drug production yields (See Table 1).

Additional issues for the industry could arise from security concerns over synthetic biology. Some worry that synthetic reagents could be used to manufacture biowarfare agents, such as anthrax. Aware of the threat, most companies screen their customers to ensure they aren't selling DNA to bad actors.

Even so, each stressed that the challenge of producing viable synthetic toxins for terrorism exceeds the capacity of most laboratories in the world today. "There are a lot of ongoing discussions in this area-the goal of all these efforts is to reduce the risk of nefarious uses for this technology without impeding the huge opportunities it allows."

Charlie Schmidt, Portland, Maine 